\title{
Efficacy of class III antiarrhythmics and magnesium combination therapy for atrial fibrillation
}

\author{
Received (first version): $28-$ Feb-20112 $\quad$ Accepted: 6-Mar-2012
}

\begin{abstract}
$^{*}$
Atrial fibrillation is a common cardiac arrhythmia, and has been a significant financial burden. Class III antiarrhythmics such as dofetilide, ibutilide, and amiodarone are indicated for rhythm control. Magnesium may possess intrinsic antiarrhythmic properties, and may potentially increase the efficacy of class III antiarrhythmics when used concomitantly.

Objective: The purpose of this article is to review the literature on the efficacy of magnesium in addition to Class III antiarrhythmics, specifically amidarone, ibutilide, and dofetilide for the cardioversion of atrial fibrillation.

Methods: Databases Pubmed and CINAHL are utilized along with the search terms amiodarone, dofetilide, ibutlide, magnesium, atrial fibrillation, conversion, rhythm control, and cardioversion.

Results: One study on dofetilide and 5 studies on ibutilide were identified. No studies were found on amiodarone. Patients with atrial fibrillation who received dofetilide and magnesium had higher rates of successful cardioversion as compared to those who only received dofetilide. Conversion rates were similar between the 2 treatment groups for patients with atrial flutter. As for ibutilide, 4 studies have shown that the addition of magnesium significantly increases conversion rates for patients with atrial fibrillation or typical atrial flutter. Conversion rates were similar for patients with atypical atrial flutter. One study showed that addition of magnesium did not improve efficacy of ibutilide. Higher doses of magnesium $(4 \mathrm{~g})$ were associated with improved outcomes. Adverse effects of magnesium were mild and included flushing, tingling, and dizziness. Patients who received magnesium had shorter corrected QT intervals and smaller increase in corrected QT interval from baseline.

Compare to previous studies, studies included in this review had higher conversion rates for dofetilide and ibutilide as well as dofetilide and magnesium or ibutilide and magnesium combination therapies. However, only 2 ibutilide studies and 1 dofetilide study reported baseline characteristics such as left atrial size, history of heart failure, and duration of atrial fibrillation, which are significant predictors of successful cardioversion. Therefore, differences in baseline demographics may have influenced the results.
\end{abstract}

*Amy WANG. PharmD, MBA, BCPS. Assistant Professor of Pharmacy Practice. Arnold and Marie Schwartz College of Pharmacy and Health Sciences, Long Island University. Brooklyn, NY (United States).
Conclusion: Magnesium may be used as adjunct for dofetilide and ibutilide due to potential improved efficacy and minimal toxicity. Dose ranging studies should be conducted in the future to establish the optimal dose and duration of therapy as well as the optimal serum magnesium concentration in order for the clinician to manage and monitor patients appropriately.

Keywords: Atrial Fibrillation. Atrial Flutter. AntiArrhythmia Agents. Magnesium Sulfate.

\section{EFICACIA DEL TRATAMIENTO DE COMBINACIÓN DE ANTIARRITMICOS CLASE III Y MAGNESIO PARA LA FIBRILACIÓN AURICULAR}

\section{RESUMEN}

La fibrilación auricular es una arritmia cardiaca frecuente, y se ha identificado como una carga financiera significativa. Los anti-arrítmicos clase III como la dofetilida, ibutilida y amiodarona están indicados para el control del ritmo. El magnesio posee propiedades intrínsecas anti-arrítmicas y potencialmente puede aumentar la eficacia de los anti-arrítimicos de clase III cuando se usa concomitantemente.

Objetivo: El objetivo de este artículo es revisar la literatura sobre la eficacia del magnesio adicionado a los anti-arrítmicos de clase III, específicamente amiodarona, ibutilida y dofetilida para la cardioversión de la fibrilación auricular.

Métodos: Se utilizaron las bases de datos Pubmed y CINAHL con los términos de busca amiodarona, dofetilida, ibutilida, magnesio, fibrilación auricular, conversión, control del ritmo y cardioversión.

Resultados: Se identificaron 1 estudio de dofetilida y 5 estudios de ibutilida. No se encontraron estudios con amiodarona. Los pacientes con fibrilación auricular que habían recibido dofetilida y magnesio tenían tasas más altas de cardioversión con éxito comparados con los que habían recibido sólo dofetilida. Las tasas de conversión fueron similares entre los dos grupos de tratamientos para pacientes con aleteo auricular. Para la ibutilida, los 4 estudios mostraron que la adición de magnesio aumenta significativamente las tasas de conversión para pacientes con fibrilación auricular o aleteo auricular típico. Las tasas de conversión fueron similares para pacientes con aleteo auricular atípico. Un estudio mostró que la adición de magnesio no mejoraba la eficacia de la ibutilida. Dosis altas de magnesio ( $4 \mathrm{~g}$ ) se asociaron a mejores resultados. Los efectos adversos del 
magnesio fueron suaves e incluyeron enrojecimiento, hormigueo y mareo. Los pacientes que recibieron magnesio tuvieron intervalos QT corregidos más cortos y menores incrementos del intervalo QT corregido.

Comparado con estudios previos, los estudios incluidos en esta revisión tenían tasas de conversión más altas para dofetilida e ibutilida, así como para tratamientos de combinación de dofetilida y magnesio o ibutilida y magnesio. Sin embargo, sólo 2 estudios de ibutilida y 1 de dofetilida comunicaron las características basales tales como tamaño auricular izquierdo, historia de fallo cardiaco, y duración de la fibrilación auricular, que son predictores significativos de éxito en la cardioversión. Por tanto, las diferencias en la demografía inicial pueden haber influenciado en los resultados.

Conclusión: El magnesio puede utilizarse como coadyuvante de dofetilida e ibutilida debido al potencial de mejorar la eficacia y su mínima toxicidad. En el futuro deberían realizarse estudios de rango de dosis para establecer la dosis óptima y la duración del tratamiento, así como la óptima concentración sérica de magnesio para que los clínicos manejen y monitoricen a los pacientes apropiadamente.

Palabras clave: Fibrilación Auricular. Aleteo Auricular. Anti-arrítmicos. Sulfato de Magnesio.

\section{INTRODUCTION}

Atrial fibrillation (AF) is a common cardiac arrhythmia with a prevalence of $0.4 \%-1 \%$. ${ }^{1}$ If left untreated, it may lead to devastating consequences such as stroke, heart failure, as well as increased risk for mortality. One of the management options for $A F$ is conversion to normal sinus rhythm using pharmacological agents, and Class III antiarrhythmics such as dofetilide, ibutilide, and amiodarone are recommended by the American College of Cardiology and the American Heart Association. ${ }^{1,2}$ Dofetilide is not available in Europe so only ibutilide and amiodarone are recommended by the European Society of Cardiology. ${ }^{3}$ However, ibutilide and dofetilide are less than $50 \%$ effective for persistent $A F$, and the efficacy of amiodarone varies between 15 to $40 \%$ for oral amiodarone and up to $95 \%$ for intravenous (IV) amiodarone. Predictors of conversion include shorter duration of $\mathrm{AF}$, smaller left atrial size, and absence of heart failure. ${ }^{1,5,6}$

Class III antiarrhythmics terminate arrhythmia mainly by blocking potassium channels, slowing down the outflow of potassium ions, and prolonging the repolarization phase of cardiac action potential. The result of potassium channel blockade is prolongation of the QT interval and increased risk of torsade de pointes, a form of polymorphic ventricular arrhythmia. ${ }^{7-9}$ Risk of developing torsade de pointes is $1-4 \%$ for ibutilide and dofetilide, and is less than $1 \%$ for amiodarone. ${ }^{9-13}$ Magnesium has intrinsic antiarrhythmic properties in that it blocks calcium and potassium channels in the heart ${ }^{14,15}$, and is an effective agent for management of torsade de pointes. ${ }^{9}$ Although not recommended in the current treatment guidelines, magnesium and Class III antiarrhythmic combination therapy for the acute rhythm control of AF have been evaluated in several studies. With a high prevalence of $\mathrm{AF}$ and serious side effects associated with antiarrhythmics, magnesium may be a useful adjunct to increase efficacy while minimize toxicity.

The purpose of this article is to review the literature on the efficacy of magnesium in addition to Class III antiarrhythmics, specifically amidarone, ibutilide, and dofetilide for the cardioversion of atrial fibrillation.

\section{METHODS}

Databases Pubmed, and CINAHL are utilized along with the search terms amiodarone, dofetilide, ibutlide, magnesium, atrial fibrillation, conversion, rhythm control, and cardioversion. Studies that compared the conversion rates of combination therapy (amiodarone, ibutilide, or dofetilide along with magnesium) versus monotherapy (amiodarone, ibutilide, or dofetilide alone or along with placebo) for conversion of AF were eligible for inclusion in this review. References of studies were evaluated for relevance to the topic, and were included if eligible.

\section{RESULTS}

One study on efficacy of dofetilide and magnesium, and 5 studies on ibutilide and magnesium combination therapy were identified. No study on the efficacy of magnesium in addition to amiodarone was found.

\section{Dofetilide}

One retrospective cohort study investigated the impact of IV magnesium therapy along with dofetilide on the success rates of chemical cardioversion in patients with AF or atrial flutter (see Table 1). A total of 160 subjects were included in the final analysis, and patients in the 2 treatment groups were comparable in age, duration of AF or atrial flutter, comorbidities, average dofetilide dose, baseline serum magnesium concentration, and prior medication therapy. Mean and standard deviation of magnesium doses were determined, but the dosing frequency and duration of therapy were not reported (see Table 1). Magnesium improved the success rates of cardioversion for dofetilide by $107 \%$ [adjusted odds ratio (OR): 2.07, 95\%Cl: 1-4.33]. After stratifying patients by their diagnosis, magnesium remains to be effective for patients with AF (adjusted OR: 2.49, 95\% Cl: 1.14-5.46), but not for those with atrial flutter (adjusted OR: 1.73, 95\% Cl: $0.88-3.38){ }^{16}$ 


\begin{tabular}{|c|c|c|c|c|c|c|}
\hline Article & Study Design & $\begin{array}{c}\text { Inclusion/ Exclusion } \\
\text { Criteria }\end{array}$ & Control group(s) & Treatment group & Doses of magnesium utilized & $\begin{array}{c}\text { Rates of Successful } \\
\text { Cardioversion }\end{array}$ \\
\hline Coleman $\mathrm{Cl}$, et al. ${ }^{16}$ & $\begin{array}{l}\text { Retrospective, } \\
\text { cohort } \\
\mathrm{N}=160\end{array}$ & $\begin{array}{l}\text { Chronic AF or AFL with } \\
\text { normal magnesium } \\
\text { levels and received } \\
\text { dofetilide for chemical } \\
\text { cardioversion }\end{array}$ & $\begin{array}{l}\text { Dofetilide alone } \\
\mathrm{N}=110\end{array}$ & $\begin{array}{l}\text { Dofetilide along with IV } \\
\text { magnesium } \\
\mathrm{N}=50\end{array}$ & $\begin{array}{l}\text { Mean (SD) first dose: } 3(2) \text { grams } \\
\text { Mean (SD) total dose during hospital stay: } \\
6(5) \text { grams } \\
\text { Magnesium was started on the same day } \\
\text { as dofetilide }\end{array}$ & $\begin{array}{lcr}\text { Treatment } & \text { group: } & 25 / 50 \\
(50 \%) & & \\
\text { Control } & \text { group: } & 42 / 110 \\
(38.2 \%) & & \end{array}$ \\
\hline Caron MF, et al. ${ }^{7}$ & $\begin{array}{l}\text { Prospective, } \\
\text { double blind, } \\
\text { randomized, } \\
\text { placebo controlled } \\
\mathrm{N}=20\end{array}$ & $\begin{array}{l}\text { AF or AFL with normal } \\
\text { renal function and } \\
\text { normal baseline } \\
\text { potassium and } \\
\text { magnesium function }\end{array}$ & $\begin{array}{l}\text { Ibutilide } \quad \text { and } \\
\text { placebo } \\
\mathrm{N}=9\end{array}$ & $\begin{array}{l}\text { Ibutilide and magnesium } \\
\mathrm{N}=11\end{array}$ & $\begin{array}{l}2 \text { grams (or matching) given over } 10 \\
\text { minutes immediately before ibutilide, } \\
\text { another } 2 \text { grams (or matching placebo) } \\
\text { given } 10 \text { minutes after ibutilide }\end{array}$ & $\begin{array}{l}\text { Treatment group: } 55 \% \\
\text { Control group: } 56 \%\end{array}$ \\
\hline Kalus JS, et al. ${ }^{17}$ & $\begin{array}{l}\text { Retrospective, } \\
\text { cohort } \\
\mathrm{N}=321\end{array}$ & AF or AFL & $\begin{array}{l}\text { Ibutilide alone (no } \\
\text { magnesium } \\
\text { received before or } \\
\text { during ibutilide } \\
\text { therapy) } \\
\mathrm{N}=214\end{array}$ & $\begin{array}{l}\text { Ibutilide + magnesium } \\
\mathrm{N}=107\end{array}$ & $\begin{array}{l}\text { Mean total dose: } 2.2 \pm 1 \text { grams } \\
\text { Magnesium was given within } 2 \text { hours } \\
\text { before or during ibutilide therapy }\end{array}$ & $\begin{array}{l}\text { Treatment group: } 72 \% \\
\text { Control group: } 60.3 \% \\
p=0.04\end{array}$ \\
\hline Patsilinakos S, et al. ${ }^{18}$ & $\begin{array}{l}\text { Prospective } \\
\mathrm{N}=476\end{array}$ & $\begin{array}{l}\text { Recent onset (within } \\
48 \text { hours) AF or AFL }\end{array}$ & $\begin{array}{l}\text { Ibutilide alone } \\
\mathrm{N}=229\end{array}$ & $\begin{array}{l}\text { Ibutilide and magnesium } \\
\mathrm{N}=247\end{array}$ & $\begin{array}{l}5 \text { grams given } 1 \text { hour prior to first dose of } \\
\text { ibutilide, followed by another } 5 \text { grams } \\
\text { given over } 2 \text { hours }\end{array}$ & $\begin{array}{l}\text { Treatment group: } 76.5 \% \\
\text { Control group: } 67.3 \% \\
p=0.033\end{array}$ \\
\hline Steinwender C, et al. ${ }^{19}$ & $\begin{array}{l}\text { Prospective, } \\
\text { randomized, single } \\
\text { blinded, placebo } \\
\text { controlled } \\
\mathrm{N}=117\end{array}$ & $\begin{array}{l}\text { Persistent symptomatic } \\
\text { typical AF or atypical } \\
\text { AF } \\
\text { Baseline QTC } \leq 440 \\
\text { ms (or } \leq 520 \mathrm{~ms} \text { for } \\
\text { amiodarone therapy) } \\
\text { Normal magnesium } \\
\text { and potassium levels }\end{array}$ & $\begin{array}{l}\text { Ibutilide } \quad \text { and } \\
\text { placebo } \\
\mathrm{N}=59\end{array}$ & $\begin{array}{l}\text { Ibutilide and magnesium } \\
\mathrm{N}=58\end{array}$ & $\begin{array}{l}\text { Magnesium } 4 \text { grams or placebo given } 20 \\
\text { minutes prior to first dose of ibutilide }\end{array}$ & $\begin{array}{l}\text { Treatment group (typical } \\
\text { AF): } 85 \% \\
\text { Control group (typical AF): } \\
59 \% \\
p=0.017 \\
\text { Treatment group (atypical } \\
\text { AF): } 48 \% \\
\text { Control group (atypical AF): } \\
56 \% \\
p=0.189\end{array}$ \\
\hline Tercius AJ, et al. ${ }^{20}$ & $\begin{array}{l}\text { Retrospective } \\
\text { cohort } \\
N=229\end{array}$ & $\begin{array}{l}\mathrm{AF} \text { or } \mathrm{AFL} \\
\text { Normal baseline } \\
\text { magnesium levels }\end{array}$ & $\begin{array}{l}\text { Ibutilide only (no } \\
\text { magnesium given } \\
\text { before or during } \\
\text { ibutilide therapy) } \\
\mathrm{N}=88\end{array}$ & $\begin{array}{l}\text { Ibutilide and magnesium } \\
\mathrm{N}=141\end{array}$ & $\begin{array}{l}\text { Magnesium 1-4 grams within } 2 \text { hours prior } \\
\text { to ibutilide (not for management of } \\
\text { ventricular arrhythmia) }\end{array}$ & $\begin{array}{l}\text { AOR: } 1.78,95 \% \text { Cl } 1.02- \\
3.09\end{array}$ \\
\hline
\end{tabular}




\section{Ibutilide}

Impact of magnesium supplementation on the efficacy of ibutilide in converting AF or atrial flutter patients was studied in 5 previous trials. ${ }^{7,17-20}$ Two of the 5 trials were retrospective. The first is a multicenter, cohort study focusing on patients with AF or atrial flutter (see Table 1). The primary endpoint was to evaluate the efficacy of ibutilide in the chemical cardioversion of AF or atrial flutter within 6 hours of administration. The treatment group consisted of patients who received IV magnesium within 2 hours before ibutilide therapy, while the control group consisted of patients who did not receive magnesium therapy prior to ibutilide. Three hundred and twenty one subjects were included, and the average doses of magnesium were calculated. Dosing frequency and duration of therapy for magnesium were not reported. Subjects in the 2 treatment groups were comparable in ibutilide dose, and baseline serum magnesium concentration. The success rate of cardioversion was $11.7 \%$ higher in the magnesium group as compared to the control group, which was significant [odds ratio (OR): $1.69,95 \% \mathrm{Cl}: 1.02-2.8$ ] (see Table 1). Incidences of ventricular arrhythmias were similar (OR: 0.66, 95\%Cl: 0.17-2.48). After patients are stratified by their initial arrhythmia, no significant differences was found between the treatment groups for AF $(67.2 \%$ for treatment group, $58.2 \%$ for control group, $\mathrm{p}=0.226$ ) or atrial flutter $(78.3 \%$ for treatment group, $64.4 \%$ for control group, $\mathrm{p}=0.109)$. $^{17}$

In 2007, another retrospective, cohort study was conducted in patients with AF or atrial flutter (see Table 1). Primary endpoint was to evaluate the impact of IV magnesium on the efficacy of ibutilide in cardioverting AF or atrial flutter. Treatment group included patients who received magnesium within 2 hours before or during ibutilide therapy (other than for treating ventricular arrhythmias), and control group included patients who did not receive magnesium. Two hundred and twenty nine patients were enrolled, and the doses of magnesium ranged from 1 to $4 \mathrm{~g}$. Baseline demographics were comparable between the 2 groups (including ejection fraction, ibutilide dose, history of heart failure, prior medication therapy, duration of AF>15 days, and left atrial size). Magnesium and ibutilide combination treatment was associated with a higher success rate for cardioversion as compared to ibutilide alone (see Table 1). A higher dose of magnesium $(4 \mathrm{~g})$ increased the odds of successful cardioversion by almost 3 fold ( $4 \mathrm{~g}$ : adjusted OR 2.98, 95\%Cl: 1.46-6.11, 1-3 g: adjusted OR 1.27, $95 \% \mathrm{Cl}: 0.69-2.33)$. One case of torsade de pointes occurred in the control group. ${ }^{20}$

In addition, 3 prospective studies were conducted. The first trial focused on patients with recent onset AF or atrial flutter (occurring within past 48 hours) (see Table 1). Patients with a history of heart failure, left ventricular ejection fraction $<35 \%$, renal dysfunction, corrected QT interval $>450 \mathrm{~ms}$, and uncorrected hypokalemia or hypomagnesemia were excluded. The treatment group received a total of $10 \mathrm{~g}$ of IV magnesium along with ibutilide while the control group only received ibutilide. Ibutilide $1 \mathrm{mg}$ was given intravenously over 10 minutes, and another $1 \mathrm{mg}$ was given if the first dose fails to convert the patients within 10 minutes. The 2 study groups were well matched in left atrial diameter, ejection fraction, and prior medication therapy. Patients who received magnesium had a $13.2 \%$ higher success rate of cardioversion as compared to the patients who only received ibutilide, and the results were significant (see table 1). Eight patients in the control group and no patients in the treatment group developed torsade de pointes $(p=0.009)$. The treatment group experienced smaller increase in corrected corrected QT interval as compared to control group (45.8ms $\mathrm{SD}=20.4$ versus $51.2 \mathrm{~ms}$ $\mathrm{SD}=26.5$, respectively, $\mathrm{p}=0.013)$, but the maximum corrected QT interval did not differ $(436.7 \mathrm{~ms}$ $\mathrm{SD}=36.4$ for treatment group, $443.2 \mathrm{~ms} S \mathrm{SD}=47.8$ for control group, $p=0.094)$. Fourteen percent of patients in treatment group experienced mild adverse effects such as flushing, tingling, and dizziness. ${ }^{18}$

The next prospective study focused on patients with persistent symptomatic typical or atypical atrial flutter (see Table 1). ${ }^{19}$ To be eligible for inclusion, patients had to have sustained palpitations or documented arrhythmia for more than 12 hours. Typical atrial flutter was defined as presence of saw-toothed like flutter waves in leads II, III, and/or aVF, along with terminal positive waves in lead V1. Any other forms of waves in those leads were defined as atypical atrial flutter. Definitions for typical or atypical atrial flutter were in accordance with standard guideline. ${ }^{21}$ Patients were randomized to receive $4 \mathrm{~g}$ of magnesium or placebo prior to ibutilide, and all patients received 1 or 2 doses of IV ibutilide $1 \mathrm{mg}$ if they did not respond to the first dose. Patients with typical or atypical atrial flutter were well matched in ejection fraction, history of heart failure, prior medication therapy, duration of arrhythmia, baseline serum magnesium and potassium concentration, and treatment assignment (magnesium or placebo). For patients with typical atrial flutter, magnesium therapy improved success rates of cardioversion. As for patients with atypical atrial flutter, magnesium and ibutilide combination therapy had lower rates of cardioversion, although the differences were not significant (See table 1). Corrected QT interval was measured 4 hours after administration of study drugs, and was not significantly different between the 2 groups $(455 \mathrm{~ms}$ $\mathrm{SD}=37$ for control group, $463 \mathrm{~ms} S D=40$ for treatment group, $p=0.282)$. Incidences of torsade de pointes were similar (2\% for control group, $3 \%$ for treatment group, $\mathrm{p}=0.375){ }^{19}$

The last prospective study investigated the effect of IV magnesium on the corrected QT interval in patients who received ibutilide. Patients were randomized to receive magnesium or matching placebo in addition to ibutilide (see table 1). Ibutilide $1 \mathrm{mg}$ (or $0.01 \mathrm{mg} / \mathrm{kg}$ if less than $60 \mathrm{~kg}$ ) was given intravenously once or twice if patient did not respond to the first dose within 10 minutes. The 2 treatment groups were similar in age, weight, and baseline serum magnesium concentration. Six patients received $1 \mathrm{mg}$ of ibutilide while 14 patients 
received $2 \mathrm{mg}$ of ibutilide. Success rates of cardioversion were compared as baseline demographics, and were similar between 2 study groups. For patients who received $1 \mathrm{mg}$ of ibutilide, success rates for cardioversion were same $(100 \%$ for treatment group, $100 \%$ for control group). For patients who received $2 \mathrm{mg}$ of ibutilide, patients who received magnesium had higher success rates of cardioversion ( $44 \%$ versus $20 \%$ ), but no statistic test was done for comparison. No torsade de pointes occurred throughout the study. Patients who received placebo experienced more significant increase in corrected QT intervals from baseline as compared to patients who received magnesium (75.1ms $\mathrm{SD}=70.3$ versus $19.2 \mathrm{~ms} \quad \mathrm{SD}=51.6$, respectively, $p<0.05){ }^{7}$

\section{DISCUSSION}

Electrophysiological studies found that administration of IV magnesium significantly delays atrioventricular node conduction, without significant effect on the sinus node. ${ }^{22}$ Efficacy of magnesium for the management of AF was investigated in 2 meta-analyses. The first meta-analysis focused on acute onset AF (defined as AF duration of less than 7 days prior to study enrollment). For conversion to normal sinus rhythm, magnesium was not more effective than calcium channel blockers or amiodarone $(p=0.17)$, or placebo $(p=0.61)$. For rate control (reduction of ventricular rate to $<100$ beats/min), magnesium was more effective when compared to placebo or calcium channel blockers $\left(p<0.00001\right.$ for both). ${ }^{23}$ Another meta-analysis focused on patients with paroxysmal or chronic AF and rapid ventricular rate. Magnesium was not more effective than placebo $(p=0.14)$ or amiodarone $(p=0.36)$, but was more effective than calcium channel blockers in restoring normal sinus rhythm $(p=0.0002)$. Magnesium was more effective than placebo $(p<0.0001)$ or calcium channel blockers $(p=0.02)$ for rate control. ${ }^{24}$ Therefore, magnesium monotherapy may be more effective for rate control, and its calcium channel blocking property may be the more dominant pharmacological activity. Efficacy of magnesium and Class III antiarrhythmics combination therapy in rhythm control of AF may be due to the additive potassium blockade effect. ${ }^{17}$

Dofetilide works by blockade of potassium channels without any effects on sodium channels, alpha adrenergic receptor, or beta adrenergic receptors. ${ }^{25}$ Dofetilide is effective for the conversion to and maintenance of normal sinus rhythm in $\mathrm{AF}$ patients ${ }^{10}$, and is safe to be used in patients with heart failure. ${ }^{13}$ Two previous trials investigated the efficacy of dofetilide for converting AF. The first trial included patients with AF or atrial flutter for 2 to 26 weeks, and found that dofetilide conversion rate was dose dependent $(6.1 \%$ for $125 \mathrm{mcg}$ BID, $9.8 \%$ for $250 \mathrm{mcg}$ BID, and $29.9 \%$ for $500 \mathrm{mcg}$ BID). In addition, dofetilide $500 \mathrm{mcg}$ twice daily was much more successful at converting atrial flutter than AF $(66.7 \%$ vs. $21.6 \%) .{ }^{10}$ The other trial focused on patients with new or worsening heart failure (New York Heart Association functional Class III or IV), and found conversion rate to be $12 \%$ at 1 month. ${ }^{3}$
In the study on dofetilide and magnesium combination therapy, efficacy of dofetilide monotherapy and of dofetilide/ magnesium combination therapy for converting $\mathrm{AF}$ is higher than that of previous studies. However, in the combination therapy study, only $30 \%$ of patients had $\mathrm{AF}$ or atrial flutter for more than 2 weeks, and only $37.5 \%$ of patients had a history of heart failure. ${ }^{16}$ As heart failure and duration of AF or atrial flutter are significant predictors of cardioversion, improved efficacy of dofetilide and dofetilide/ magnesium combination therapy in the combination therapy study may be due to the differences in baseline demographics from the previous studies. As only 1 retrospective study has shown the improved efficacy of combination therapy in the rhythm control of AF, whether magnesium improves efficacy of dofetilide is uncertain. Future studies should be conducted to include a higher proportion of patients with a history of heart failure and duration of $\mathrm{AF}$ or atrial flutter for more than 2 weeks.

Ibutilide is another class III antiarrhythmic. In addition to blocking outward flow of potassium ions, ibutilide also activates slow inward sodium ions, channels, prolonging the repolarization phase and refractory period of cardiac action potential. ${ }^{16,26}$ Two previous trials have shown that ibutilide is more efficacious for conversion of atrial flutter over AF. In one study, average duration of AF prior to cardioversion was 12-16 days, average left atrial size was $4.5-4.6 \mathrm{~cm}$, and $>70 \%$ of patients had a history of heart disease6. The other study did not report history of heart failure, duration of $\mathrm{AF}$, and left atrial size. ${ }^{27}$ After 2 doses of $1 \mathrm{mg}$ IV ibutilide, overall conversion rate ranged between $26.1 \%$ and $47 \%{ }^{6,27}$ Based on the results of the trials included in this review, efficacy of ibutilide alone for AF or atrial flutter is around $60 \%$, and the addition of magnesium improves the conversion rate to 72 $85 \%$. $^{17,18,20}$ However, only 3 trials reported left atrial size, past medical history, and duration of AF of the subjects. Left atrial size and duration of AF were comparable to that of previous study, but only $30 \%$ to $40 \%$ of patients had a history of heart failure. ${ }^{18-20}$ Differences in baseline characteristics may have influenced the conversion rates of ibutilide or ibutilide and magnesium combination therapy.

Magnesium may be a more useful adjunct therapy to ibutilide than it is for dofetilide. Side effects of magnesium are usually mild and usually include minor tingling, flushing, and dizziness ${ }^{18}$, and serious side effects may include hypotension, bradycardia, or atrioventricular block. ${ }^{23}$ Therefore, administering magnesium in combination with ibutilide or dofetilide involves minimal risks with close monitoring of vital signs and electrocardiograms, and may increase success rates of cardioversion. Moreover, magnesium has been shown to prevent significant prolongation of corrected QT interval post antiarrhythmic therapy, and thus, reduce risks of torsade de pointes. ${ }^{7,9,16}$ Magnesium may be added to ibutilide for conversion of $\mathrm{AF}$ or atrial flutter except for atypical atrial flutter. As higher doses of magnesium are associated with improved efficacy, $4 \mathrm{~g}$ of magnesium may be given prior to first dose of ibutilide. ${ }^{20}$ As the optimal dose, frequency, or 
duration of magnesium therapy has not been established for dofetilide, $2 \mathrm{~g}$ of IV magnesium, the recommended dose for management of torsade de pointes, may be used. ${ }^{9}$ Additionally, higher baseline magnesium concentration has been associated with higher success rates of cardioversion ${ }^{28}$, but the optimal concentration after magnesium therapy has not been established as it was rarely monitored. In the future, dose ranging studies as well as studies aiming at finding a correlation between serum magnesium concentration and efficacy should be conducted so that the clinicians can dose and monitor magnesium therapy appropriately.

\section{CONCLUSIONS}

Four grams of magnesium may be given within 2 hours prior to initiation of ibutilide for conversion of AF or typical atrial flutter, but not for atypical atrial flutter. Two grams of magnesium may be given in addition to dofetilide, and additional doses may be given if necessary. Dosing ranging studies should be conducted for magnesium and ibutilide or dofetilide combination therapies in order to establish the optimal dose, frequency, serum concentration, and duration of therapy.

\section{CONFLICT OF INTEREST}

None.

Funding: None.

\section{References}

1. American College of Cardiology, American Heart Association, and European Society of Cardiology. ACC/AHA/ESC 2006 Guidelines for the management of patients with atrial fibrillation: a report of the American College of Cardiology/American Heart Association Task Force on Practice Guidelines and the European Society of Cardiology Committee for Practice Guidelines (Writing Committee to revise the 2001 guidelines for the management of patients with atrial fibrillation). J Am Coll Cardiol. 2006;48(4):e149-e246.

2. American College of Cardiology, American Heart Association, and European Society of Cardiology. 2011 ACCF/AHA/HRS Focused update on the management of patients with atrial fibrillation (updating the 2006 guideline). J Am Coll Cardiol. 2011;57(2):223-242.

3. Khan IA, Mehta NJ, Gowda RM. Amiodarone for pharmacological cardioversion of recent-onset atrial fibrillation. Int J Cardiol. 2003;89(2-3):239-248.

4. Galve E, Rius T, Ballester R, Angeles Artaza M, Arnau JM, Garcia-Dorado D, Soler-Soler J. Intravenous amiodarone in treatment of recent-onset atrial fibrillation: results of a randomized, controlled study. J Am Coll Cardiol. 1996;27(5):10791082

5. Stambler BS, Wood MA, Ellenbogen KA, Perry KT, Wakefield LK, VanderLugt JT. Efficacy and safety of repeated intravenous doses of ibutilide for rapid conversion of atrial flutter or fibrillation. Circulation. 1996;94(7):1613-1621.

6. Caron MF, Kluger J, Tsikouris JP, Ritvo A, Kalus JS, White CM. Effects of intravenous magnesium sulfate on the QT interval in patients receiving ibutilide. Pharmacotherapy. 2003;23(3):296-300.

7. White CM, Xie J, Chow MSS, Kluger J. Prophylactic Magnesium to Decrease the Arrhythmogenic Potential of Class III Antiarrhythmic Agents in a Rabbit Model. Pharmacotherapy. 1999;19(5):635-640.

8. American Heart Association and the American College of Cardiology Foundation. Prevention of torsade de pointes in hospital settings. J Am Coll Cardiol. 2010;55(9):934-947.

9. Singh S, Zoble RG, Yellen L, Brodsky MA, Feld GK, Berk M, Billing CB. The efficacy and safety of oral dofetilide in converting to and maintaining sinus rhythm in patients with chronic atrial fibrillation or atrial flutter: the symptomatic atrial fibrillation investigative research on dofetilide (SAFIRE-D) study. Circulation. 2000;102(19):2385-2390.

10. Wolbrette DL. Risk of proarrhythmia with class III antiarrhythmic agents: sex-based differences and other issues. Am J Cardiol. 2003;91(6A):39D-44D.

11. Spearritt D. Torsades de pointes following cardioversion: case history and literature review. Aust Crit Care. 2003;16(4):144-149.

12. Torp-Pedersen C, Møller M, Bloch-Thomsen PE, Køber L, Sandøe E, Egstrup K, Agner E. Dofetilide in patients with congestive heart failure and left ventricular dysfunction. New Engl J Med, 1999;341(12):857-865.

13. Reinhart RA. Clinical correlates of the molecular and cellular actions of magnesium on the cardiovascular system. Am Heart J. 1991;121(5):1513-1521.

14. White RE, Hartzell HC. Magnesium in cardiac function: regulator of ion channels and second messengers. Biochem Pharmacol. 1989;38(6):859-867.

15. Coleman Cl, Sood N, Chawla D, Talati R, Ghatak A, Kluger J. Intravenous magnesium sulfate enhances the ability of dofetilide to successfully cardiovert atrial fibrillation or flutter: results of the Dofetilide and Intravenous Magnesium Evaluation. Europace. 2009;11(7):892-895.

16. Kalus JS, Spencer AP, Tsikouris JP, Chung JO, Kenyon KW, Ziska M, Kluger J, White CM. Impact of prophylactic i.v. magnesium on the efficacy of ibutilide for conversion of atrial fibrillation or flutter. Am J Health Syst Pharm. 2003;60(22):2308-2312.

17. Patsilinakos S, Christou A, Kafkas N, Nikolaou N, Antonatos D, Katsanos S, Spanodimos S, Babalis D. Effect of high doses of magnesium on converting ibutilide to a safe and more effective agent. Am J Cardiol. 2010;106(5):673-676.

18. Steinwender C, Hönig S, Kypta A, Kammler J, Schmitt B, Leisch F, Hofmann R. Pre-injection of magnesium sulfate enhances the efficacy of ibutilide for the conversion of typical but not of atypical persistent atrial flutter. Int $\mathrm{J}$ Cardiol. 2010;141(3):260-265. 
19. Tercius AJ, Kluger J, Coleman $\mathrm{Cl}$, White $\mathrm{CM}$. Intravenous magnesium sulfate enhances the ability of intravenous ibutilide to successfully convert atrial fibrillation or flutter. Pacing Clin Electrophysiol. 2007;30(11):1331-1335.

20. Rasmussen HS, Thomsen PE. The electrophysiological effects of intravenous magnesium on human sinus node, atrioventricular node, atrium, and ventricle. Clin Cardiol. 1989;12(2):85-90.

21. Ho KM, Sheridan DJ, Paterson T. Use of intravenous magnesium to treat acute onset atrial fibrillation: a meta-analysis. Heart. 2007;93(11):1433-1440.

22. Onalan O, Crystal E, Daoulah A, Lau C, Crystal A, Lashevsky I. Meta-analysis of magnesium therapy for the acute management of rapid atrial fibrillation. Am J Cardiol. 2007;99(12):1726-1732.

23. Tikosyn® Package Insert. Pfizer Labs. Revised November 2006.

24. Granberry MC. Ibutilide: a new class III antiarrhythmic agent. Am J Health Syst Pharm. 1998;55(3):255-260.

25. Abi-Mansour P, Carberry PA, McCowan RJ, Henthorn RW, Dunn GH, Perry KT. Conversion efficacy and safety of repeated doses of ibutilide in patients with atrial flutter and atrial fibrillation. Am Heart J. 1998;136(4 Pt 1):632-642.

26. Gullestad L, Birkeland K, Mølstad P, Høyer MM, Vanberg P, Kjekshus J. The effect of magnesium versus verapamil on supraventricular arrhythmias. Clin Cardiol. 1993;16(5):429-434. 